\title{
GAS TURBINE IMPELLERS FREE VIBRATION STUDY USING THE FEM ANALYSIS
}

\author{
S.O. Morhun, $\mathrm{PhD}$ \\ Lecturer, Department of Engineering Mechanics and Technology of Machine Building \\ Admiral Makarov National University of Shipbuilding, Ukraine
}

\begin{abstract}
In this paper the problem of gas turbine rotor impellers free vibration has been studied. For its solution, the new, more correct mathematical model on the base of the nonlinear FEM has been designed. All calculations have been held for the two types of boundary conditions $(C-C$ and $C-\mathrm{S}$ ) that match the most common types of the turbine rotors assembling. By the usage of the designed mathematical model several rotor impellers free vibration modes and frequencies have been calculated. The developed mathematical model adequacy has been verified by the comparison of calculated results with the experimental data.
\end{abstract}

Key words: turbine rotor, impellers, free vibration, finite elements method, vibration modes and frequencies.

\section{Introduction.}

In the modern world one of the most important trends in the power machine building, marine and aircraft engine building areas is a sharp increase of the gas turbine engines power. But such increase imperatively demands from the designers to complement the whole turbine structure and its main units' durability. Thus we have a need to find out the details and assembly units of the turbine that are extremely loaded. Without any hesitation the turbine rotor should be taken into consideration, because it works under influence of non-stationary gas flow of extremely high temperature. Of course the vibration unfavorable factors influence on the impeller are more sufficient and their impact in the gas turbine rotors breakdowns is more important.

Due to the high cost of the modern high power gas turbines it's very important to develop the more correct mathematical models and numerical methods for their vibration characteristics calculations during the designing process. So despite the intense studies in this area [1-8] there are several important questions left unstudied. That's why the problem of the gas turbine rotor impellers free vibration studying by calculating its vibration modes and frequencies is rather actual.

\section{Literature Review and the Problem Statement}

Firstly the impeller blades have been considered as a unity of stiff rods or even plates $[9,10]$. According to this approach the Bubnov-Halerkin's method was used to calculate the frequency of only one blade. It was considered that all other blades vibrate with the same frequency. So the turbine rotor impeller was simulated only by the vibration of one blade. Of course such approach was incorrect, because in reality the turbine blades are shaped by space curves and their geometric form is sharply different from the rods or even plates.

In modern literature the main issues of the gas turbine rotors correct design and especially strength calculations are linked with the finite element method (FEM) 
usage. In the paper [9], compressor and also turbine rotors models on the base of FEM are given. But the main disadvantage of these models is an incorrect description of blades feather by the plane finite elements of triangular type. These circumstances sharply decrease the reliability of the obtained results. To prevent all these disadvantages, in the papers $[4-6,11,12]$ the three-dimensional finite element models are used. For example, in [4] special five-node finite elements of pyramid type were applied for the rotor modeling. For the turbine blades bandage modeling, the eight-node finite elements of prismatic type were also used. In the paper [5], the authors simulate the blade's feather using the eight-node finite elements of prismatic type and in the paper [6] - four-node finite elements of shell type.

But, as it has been mentioned above, the gas turbine rotor impeller consists of the blades that can be correctly described only by the space curvilinear finite elements. Such elements have been developed in papers [3, 12, 13], but all calculations have been held only for single blades. Thus the problem of the rotor impeller vibration characteristics calculation on the base of the space curvilinear finite elements usage has been out of the question till that time.

There are also several experimental methodologies that could be applied for the research of the impeller free vibration modes [10]. But all of them are very expensive.

\section{The Aim and Main Tasks of the Study}

The main aim of this work is to research the gas turbine rotor impeller as a solid body free vibration process for two different types of boundary conditions. The first three most dangerous vibration modes and frequencies of the impeller should also be calculated.

To achieve the aim of the work, the following tasks have been set:

- to develop a more correct mathematical model of the gas turbine rotor impeller free vibration state on the base of three-dimensional curvilinear finite elements;

- to study the influence of the rotor blades boundary conditions (conditions of the rotor assembly formation) on the whole impeller free vibration modes and frequencies value;

- to compare the obtained by the numerical calculation results with the experimental data and take a decision about an adequacy of the designed mathematical model and its usefulness for the further researches.

\section{Main Materials of the Study}

\subsection{Model of the gas turbine impeller section and its boundary conditions}

The gas turbine rotor impeller can be considered as a cyclically symmetric system, which consists of several sections with equal geometric, inertial and stiff parameters. Each section includes the blade, the corresponding disk sector and the bandage or damping links due to the assembling scheme (fig. 1). Indexes $a, b$ and $c$ are used to mark the left border, middle part and the right border of the section.

The described impeller section is located in the right rectangular Cartesian coordinate system $X Y Z$. The $Z$ axis is normal to the turbine rotor axis of rotation; $X$ axis matches the turbine rotor axis of rotation. The whole coordinate system is rotating with constant angular velocity together with the rotor.

To study the shown section free vibration by means of FEM let's use the Lagrange variation principle (1). Thus: 


$$
\frac{\partial L}{\partial q_{i}}-\frac{d}{d t}\left(\frac{\partial L}{\partial \dot{q}_{i}}\right)=0, i=1, \ldots ., n,
$$

where $L$ - Lagrange function, $q_{i}$ - generalized coordinate of the $i$ node of the section finite elements model, $n$ - the quantity of the finite element nodes.

The whole section is modeled by three types of the finite elements. The turbine blade, which is the most important part of the impeller, is approximated by curvilinear space finite elements with eight nodes. The disk is properly described by the space finite elements of hexagon type with eight nodes. And the bandages or damping links are formed by prismatic finite elements with eight nodes two. The extended description of the reasons why such finite elements have been chosen, their shape functions and fields of displacement are given in papers [13, 14].

After the nonlinear FEM approximation of the impeller section (fig. 1) on the base of (1) we receive the canonic equation of the solid body vibration in matrix form (2). Thus:

$$
[M]\left\{\frac{d^{2} \delta}{d t^{2}}\right\}+[C]\left\{\frac{d \delta}{d t}\right\}+[K]\{\delta\}=\{F\},
$$

where $[M]$ - the FEM model mass matrix; $[C]$ - the FEM model damping matrix; $[K]$ - the FEM model stiffness matrix; $\{\delta\}$ - the FEM model generalized displacement vector; $\{F\}$ - the vector of external forces.

As we take into consideration only the rotor's free vibration, then the elements of damping matrix and the vector of external forces are equal to zero. So the matrix equation (2) is transformed to matrix equation (3):

$$
[M]\left\{\frac{d^{2} \delta}{d t^{2}}\right\}+[K]\{\delta\}=0,
$$

According to the gas turbine rotor assembling schemes there are two types of the impellers - the impellers with bandages and the impellers with damping links. That's why we have to take into consideration two types of boundary conditions. They are $C-C$ for the impeller with bandages and $C-S$ for the impeller with damping links.

\subsection{Amplitudes of the gas turbine rotor impeller free vibration.}

The solution of matrix equation (3) can be found by spreading out the section generalized displacement in trigonometric row. So:

$$
\delta_{J}=a_{J}^{1} \cos (\omega t)+a_{J}^{2} \sin (\omega t), J=1,2, \ldots, m,
$$

where $m$ is a quantity of the finite elements model nodes, $\omega-$ angular velocity of the rotor rotation.

The indexes 1 and 2 would be used later to differentiate the amplitudes belonging to $\cos (\omega t)$ and $\sin (\omega t)$. 
After putting the equation (4) into the equation (3) we will receive next system of matrix equations:

$$
\begin{aligned}
& \Lambda_{1 a} a_{a}^{1}+\Lambda_{1 b} a_{b}^{1}+\Lambda_{1 c} a_{c}^{1}+\Lambda_{1 a} a_{a}^{2}+\Lambda_{1 b} a_{b}^{2}+\Lambda_{1 c} a_{c}^{2}=0, \\
& \Lambda_{2 a} a_{a}^{1}+\Lambda_{2 b} a_{b}^{1}+\Lambda_{2 c} a_{c}^{1}+\Lambda_{2 a} a_{a}^{2}+\Lambda_{2 b} a_{b}^{2}+\Lambda_{2 c} a_{c}^{2}=0, \\
& \Lambda_{3 a} a_{a}^{1}+\Lambda_{3 b} a_{b}^{1}+\Lambda_{3 c} a_{c}^{1}+\Lambda_{3 a} a_{a}^{2}+\Lambda_{3 b} a_{b}^{2}+\Lambda_{3 c} a_{c}^{2}=0,
\end{aligned}
$$

where $\Lambda_{I J}=\left[K_{I J}\right]-f^{2}\left[M_{I J}\right], \Lambda_{I J}-$ blocks of the impeller section dynamic stiffness matrix; $f$ - the impeller free vibration frequency.

Solution of matrix equations systems (5) gives us an opportunity to calculate the unknown impeller free vibration frequency.

\section{Main results of the study and their analysis}

The aforementioned gas turbine rotor impellers are made out of heat resistant alloy X2CrNiMo 17-34-3, which has the following parameters: density $\rho=8100 \mathrm{~kg} / \mathrm{m} 3$; Young's modulus $E=1.79 * 10^{6} \mathrm{MPa}$; Poison's ratio $v=0.3$ [14]. The quantity of the blades in the impeller is 80 . The disk diameter $d=500 \mathrm{~mm}$; the blade's height $h=120 \mathrm{~mm}$.

First let's take into consideration the rotor impellers free vibration modes (fig. 2-4).

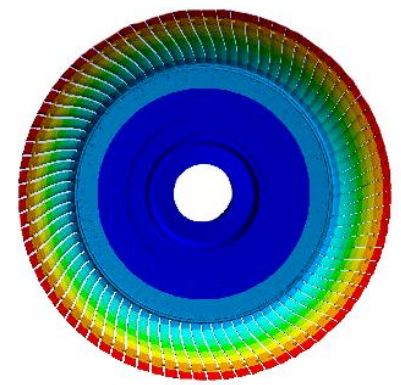

(a)

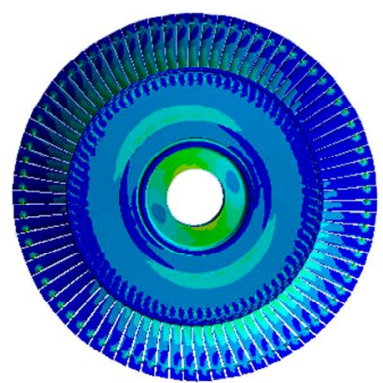

(b)

Fig. 2. The impeller free vibration mode with one nodal diameter

(a) - impeller with damping links (boundary conditions $C-S$ ); (b) - impeller with bandages (boundary conditions $C-C$ )

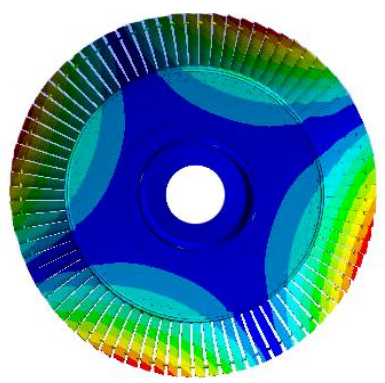

(a)

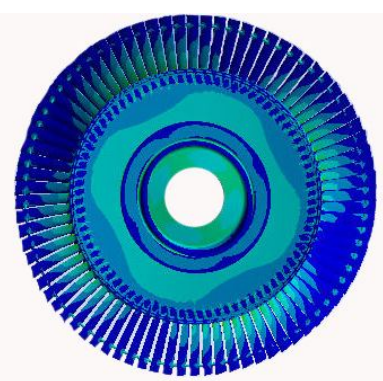

(b)

Fig. 3. The impeller free vibration mode with two nodal diameters

(a) - impeller with damping links (boundary conditions $C-S$ ); (b) - impeller with bandages (boundary conditions $C-C$ ) 


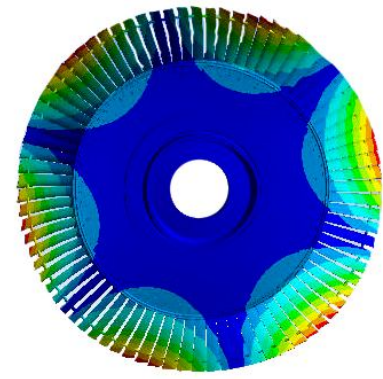

(a)

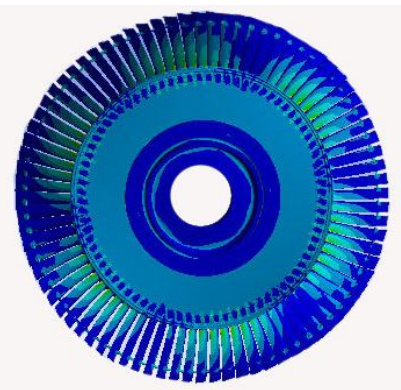

(b)

Fig. 4. The impeller free vibration mode with three nodal diameter

(a) - impeller with damping links (boundary conditions $C-S$ ); (b) - impeller with bandages (boundary conditions $C-C$ )

According to the data, given on the fig. $2-4$, we can find out that for two types of boundary conditions the modes of impeller free vibration are practically similar. The mode with one nodal diameter almost corresponds the well-known first flexural vibration form for solid bodies. Displacements of the impellers with bandages are much slighter (blue color on fig. $2-4$ (b)), than the displacement of impellers with damping links (red color on fig.2 - 4(a)). These facts don't contradict the main postulates of the oscillation theory. But there are some differences too. It should be mentioned that for the impeller with damping links the nodal diameters are more obvious. The explanation of this fact is their higher ductility. On the other hand the vibration mode for all types of impellers changes from the bending mode at the peripheral antinodes to the torsion mode near the nodal diameters.

For taking the decision about the developed mathematical model adequacy, we should compare the calculated impeller vibration frequencies with the experimental data (table 1). The experimental methodology is given in the paper [10]. The experiment has been held for three same impellers with damping links.

Table 1

The impeller free vibration frequencies for the first three modes

\begin{tabular}{|c|c|c|c|}
\hline \multirow{2}{*}{ Nodal diameter } & \multicolumn{2}{|c|}{ Free vibration frequency $f, \mathrm{~Hz}$} & Divergence, \\
\cline { 2 - 3 } & Calculated data & Experimental data & 7,3 \\
\hline 1 & 112 & $105-108$ & 9,14 \\
\hline 2 & 549 & $485-502$ & 12,8 \\
\hline 3 & 1086 & $921-957$ & \\
\hline
\end{tabular}

Analyzing the data, represented in table 1, we can conclude that the divergence between the calculated results and experimental data is less than $15 \%$.

\section{Conclusions}

It has been possible to develop the new refined mathematical model of gas turbine rotor impellers free vibration. The matter is that this model gives an opportunity to take into consideration the turbine blades constructional inhomogeneity, in particular their space curvilinear form with sharp inflections. 
It gives the designers an opportunity to calculate the free vibration modes and frequencies for turbo machinery rotors of various types and assembling schemes.

On the base of the developed mathematical model usage the free vibration characteristics of gas turbine rotor impellers of two main types have been calculated. Two different boundary conditions have been taken into consideration. It was found that for both types of impellers the free vibration modes are practically similar due to the nodal diameters location.

The calculated frequencies of the gas turbine impeller free vibration have been compared with the experimental data. The divergence between the obtained results and experimental data has been found too. Such low percentage of divergence shows us that the developed mathematical model is adequate and could be used for further calculations in the field of gas turbine rotor dynamics. Especially it will be useful for the studies of gas turbine rotors stress-strain state, caused by complex effect of forced vibration and thermal load.

\section{REFERENCES}

1. Samaras C. Emissions and lifetime estimation modeling of industrial gas turbines. / C. Samaras // M. Sc. Progress Review, Cranfield University, UK, 2009. P. 30-35.

2. Krishnakanth P. V. Structural and Thermal Analysis of Gas Turbine Blade by using FEM / P. V. Krishnakanth, G. Narasa Raju et. al. // International Journal of Scientific Research Engineering and Technology. 2013 Vol. 2, Issue 2. P. 060-065.

3. Mrinaline M. Steady state structural analysis of single crystal turbine blade / M. Mrinaline // International Journal of Engineering Research and Technology. 2016. Vol. V5, Issue 10. P. 382 384. doi: $10.17577 /$ ijertv5is100314

4. Ugargol R. Life estimation of turbine blisk for a gas turbine engine / R. Ugargol, K. S. Narayanaswamy, C.V. Sesha Kumar // International Journal of Mechanical Engineering and Technology. 2017. Vol. 8, Issue 8. P. 393-399.

5. Rzadkowski $R$. Unsteady forces acting on the rotor blades in the turbine stage in $3 D$ viscous flow in nominal and off-design regimes / R. Rzadkowski, V. Gnesin, L. Kolodyazhnaya // Journal of Vibration Engineering, and Technologies. 2014. Vol. 2, Issue 2. P. 89-95.

6. Baqersad J. Predicting full-field dynamic strain on a three-bladed wind turbine using three dimensional point tracking and expansion techniques / J. Baqersad, C. Niezrecki, P. Avitabile // Sensors and Smart Structures Technologies for Civil, Mechanical, and Aerospace Systems 2014. 2014. doi: $10.1117 / 12.2046106$

7. Postnov V.V. Theoretical and experimental stress-strain analysis of machining gas turbine engine parts made of the high energy structural efficiency alloy / V. V. Postnov, S. V. Starovoitov, S. Yu. Fomin, R. R. Basharov // Journal of Engineering Science and Technology Review. 2014. Vol. 7, Issue 5. P. 47-50.

8. Bitkina $O$. Experimental and theoretical analysis of the stress-strain state of anisotropic multilayer composite panels for wind turbine blade / O. Bitkina, K.-W. Kang, J.-H. Lee // Renewable Energy. 2015. Vol. 79. P. 219-226. doi: 10.1016/j.renene.2014.11.004

9. Kostyuk A.G. Dinamika i prochnost' turbomashin (Dynamics and strength of turbines) / A. G. Kostyuk // Moscow: Mashinostroenie, 1982. 264 p.

10. Vorobiev Yu.S. Kolebaniya lopatochnogo apparata turbomashin (Vibration of the turbine blades systems ) / Yu. S. Vorobiev // Kyiv: Naukova dumka, 1988. 224 p.

11. Sosunov V.A. Teoriya, raschet i proektirovanie aviacionnyh dvigateley i energeticheskih ustanovok (The theory, calculation and design of the aircraft engines) / V. A. Sosunov, V. M. Chepkin // Moscow: Mosk.energ. in-t., 2003. 677 p.

12. Pyhalov A.A. Staticheskiy i dinamicheskiy analiz sbornyh rotorov turbomashin (Static and dynamic analysis of the turbine rotors assemblies) / A. A. Pyhalov, A. E. Milov // Irkutsk: Izd-vo Irkut. tekhn. un-ta, 2007. $194 \mathrm{p}$.

13. Morgun $S$. The blades constructions finite elements models development / S. Morgun // Bulletin of the National Technical University «KhPI». Series: New Solutions in Modern Technologies. 2016. Issue 42 (1214). P. 86-91. doi: 10.20998/2413-4295.2016.42.14 
14. Morhun S. The influence of the blade feather constructional inhomogeneity on the turbine cooling blades stress-strain state // Eastern-European Journal of Enterprise Technologies. Series: Applied Mechanics. 2018. Issue 2/7 (92). P. 11-17. DOI: 10.15587/1729-4061.2018.125937.

Стаття надійшла до редакиії 06.12.2018 р.

Morhun $S$.

GAS TURBINE IMPELLERS FREE VIBRATION STUDY USING THE FEM ANALYSIS

Due to the rather hard working process gas turbine engines rotor impellers are always heavily influenced by the unfavourable factors of the gas flow. So the close attention should be paid to the vibration processes in the rotor. More worse is the fact that the impeller consists of blades, which have a curvilinear geometric form. So they can't be correctly described by the theory of plates or even by the plate finite elements. That's why the problem can be solved only by the usage of space curvilinear finite elements on the base of which the mathematical model is built. The whole impeller can be considered as a cyclically symmetric system. Thus it can be divided into several sections, one of which would be studied. After the nonlinear FEM approximation of the aforementioned impeller's section we receive a canonic matrix equation of the solid body vibration state. As in this study only the problem of the impeller free vibration is taken into consideration, than the matrix of damping and the vector of external forces are equal to zero. After making all necessary preparations, we find out the section free vibration modes and frequencies. All calculations were held for two types of boundary conditions that are chosen according to the impellers assembling schemes. Calculated results have been compared with the experimental data. As the divergence between them is less than $15 \%$, than the developed mathematical model is adequate. The developed mathematical model and obtained results could be used for the gas turbine rotors forced vibration and stressstrain state study.

Key words: turbine rotor, impellers, free vibration, finite elements method, vibration modes and frequencies.

Моргун С.О.

ДОСЛІДЖЕННЯ ВЛАСНИХ КОЛИВАНЬ ЛОПАТКОВИХ ВІНЦІВ ГАЗОТУРБІННОГО ДВИГУНА ЗА ДОПОМОГОЮ СКІНЧЕНО ЕЛЕМЕНТНОГО АНАЛІЗУ

Досліджується питання власних коливань лопаткових вінців ротора газотурбінного двигуна. Для цього розроблена удосконалена математична модель власних коливань вінця з використанням тривимірних криволінійних скінчених елементів. Лопатковий вінець може бути представлений в якості суперпозиції секторів, кожний $з$ яких включає в себе сектор диску та лопатку 3 між лопатковими зв'язками. Для моделювання пера лопатки та сектору диску лопаткового вінця використовуються криволінійні скінчені елементи гексагонального типу, що мають по вісім вузлів 3 трьома ступенями вільності. Бандажна та коренева полиці лопатки змодельовані також тривимірними скінченими елементами, але призматичного типу. Дослідження проведено для лопаткових вінців, що мають демпферні між лопаткові зв'язки. Охолоджувані лопатки мають у порожнині пера сітку каналів для плину охолоджуючого повітря. Стінки цих каналів являють собою ребра жорсткості у порожнині пера. Тому для коректного моделювання порожнистого пера лопатки були використані оболонкові скінчені елементи.

Всі розрахунки виконано для двох типів граничних умов $(C-C$ та $C-S)$, що відповідають найбільш поширеним типам компонування роторів. За допомогою розробленої математичної моделі визначено частоти та форми власних коливань лопаткових вінців ротора газотурбінного двигуна. Адекватність розробленої математичної моделі підтверджується порівнянням результатів розрахунку та даних експерименту. Розбіжність між результатами розрахунків та експерименту не перевищу $15 \%$.

Розроблена математична модель та отримані на ії основі результати можуть бути використані для подальших розрахунків віброміцності, вібростійкості роторів газотурбінних двигунів, а саме при визначенні їх напружено-деформованого стану.

Ключові слова: ротор газотурбінного двигуна, лопаткові вінці, вільні коливання, метод скінчених елементів, граничні умови, частоти та форми коливань.

Моргун C.A.

ИССЛЕДОВАНИЕ СОБСТВЕННЫХ КОЛЕБАНИЙ ЛОПАТОЧНЫХ ВЕНЦОВ ГАЗОТУРБИННОГО ДВИГАТЕЛЯ С ПОМОЩЬЮ КОНЕЧНО-ЕЛЕМЕНТНОГО АНАЛИЗА

Исследуются собственные колебания лопаточных венцов ротора газотурбинного двигателя. Для этого разработана уточненная конечно-элементная модель собственных 
колебаний венца с использованием трехмерных криволинейных конечных элементов. Все расчеты выполнены для двух типов граничных условий $(C-C$ и $C-S)$, которые соответствуют наиболее распространенным вариантам компоновки роторов. На основе разработанной математической модели определены частоты и формы собственных колебаний лопаточных венцов ротора газотурбинного двигателя. Адекватность разработанной математической модели подтверждается сравнениями результатов расчета с данными, полученными экспериментальным путем.

Ключевые слова: ротор газотурбинного двигателя, лопаточные венцы, свободные колебания, метод конечных элементов частоты и формы колебаний.

\section{УДК 539.3}

Моргун С.О. Дослідження власних коливань лопаткових вінців газотурбінного двигуна за допомогою скінчено елементного аналізу // Опір матеріалів і теорія споруд: наук.-тех. збірн. - К.: КНУБА, 2019. - Вип. 102.- С. 69-76.

Досліджуються власні коливання лопаткових вінців ротора газотурбінного двигуна на основі розробленої удосконаленої математичної моделі з використанням тривимірних криволінійних скінчених елементів. Адекватність математичної моделі підтверджується порівнянням результатів розрахунку та даних експерименту.

Табл. 1. Іл. 4. Бібліогр. 14 назв.

\section{UDC 539.3}

Morhun S.O. Gas turbine impellers free vibration study using the fem analysis // Strength of Materials and Theory of Structures: Scientific-and-technical collected articles - Kyiv: KNUBA, 2019. - Issue 102. - P. 69-76.

The free vibration of the gas turbine rotor impellers are studied on the basis of the developed advanced mathematical model with the use of three-dimensional curvilinear finite elements. The adequacy of the mathematical model is confirmed by comparing the results of the calculation and the experimental data.

Tabl. 1. Fig. 4. Ref. 14.

\section{УДК 539.3}

Моргун С.А. Исследование собственных колебаний лопаточных венцов газотурбинного двигателя с помощью конечно-элементного анализа // Сопротивление материалов и теория сооружений: науч.-тех. сборн. - К.: КНУСА, 2019. - Вып. 102. - С. 69-76.

Исследуются собственные колебания лопаточных вениов ротора газотурбинного двигателя на основе разработанной усовершенствованной математической модели с использованием трехмерных криволинейных конечных элементов. Адекватность математической модели подтверждается сравнением результатов расчета и данных эксперимента.

Табл. 1. Ил. 4. Библиогр. 14 назв.

Автор (науковий ступінь, вчене звання, посада): Моргун Сергій Олександрович, канд. техн. наук, доцент без вченого звання, кафедра «Інженерної механіки та технології машинобудування», Національний університет кораблебудування ім. адмірала Макарова

Адреса робоча: 54025, Украӥна, м. Миколаӥв, просп. Героїв Украӥни, 9, Начіональний університет кораблебудування ім. адмірала Макарова, кафедра інженерної механіки та технології машинобудування, МОРГУНУ Сергію Олександровичу.

Мобільний тел.: +38(050)393-28-75

Email:serhii.morhun@nuos.edu.ua

ORCID ID: http://orcid.org/0000-0003-2881-7541

SCOPUS ID: 57201675974

Serhii Morhun, PhD, Lecturer, Department of Engineering Mechanics and Technology of Machinebuilding, Admiral Makarov National University of Shipbuilding

Adr.: Heroiv Ukrainy ave. 9, Mykolaiv, Ukraine, 54025

Phone: (+38)050. 393.28.75

Email:serhii.morhun@nuos.edu.ua

ORCID ID: http://orcid.org/0000-0003-2881-7541

SCOPUS ID: 57201675974 